Psedno-Cholinesterasf Activity of Dog's Pancreatic Juice AND PANCREAS

\begin{tabular}{|c|c|c|c|c|}
\hline \multirow[b]{2}{*}{ Exp. } & \multicolumn{3}{|c|}{ Pancreatic juice secreted in response to: } & \multirow[b]{2}{*}{$\begin{array}{l}\text { Pancreas } \\
\text { (units/gm.) }\end{array}$} \\
\hline & $\begin{array}{l}\text { Pilocarpine } \\
\text { (units/mil.) }\end{array}$ & $\begin{array}{c}\text { Secretin } \\
\text { preparation } \\
\text { (units/ml.) }\end{array}$ & $\begin{array}{l}\text { Vagal stim- } \\
\text { ulation dur- } \\
\text { ing secretin } \\
\text { flow } \\
\text { (units } / \mathrm{ml} \text {.) }\end{array}$ & \\
\hline I & 3,240 & 420 & - & 1,450 \\
\hline II & 1,380 & 1,080 & 1250 & 2,000 \\
\hline III & $\begin{array}{l}2,700 \\
2,870\end{array}$ & $\begin{array}{l}765 \\
960\end{array}$ & $\begin{array}{l}1470 \\
1870\end{array}$ & 2,570 \\
\hline
\end{tabular}

The activity of the pseudo-cholinesterase in the pancreatic secretion of three dogs is shown in the accompanying table.

The results indicate that pseudo-cholinesterase can be present in high concentration in the pancreatic juice of the dog, and in these experiments the amounts appeared to vary according to the stimulus employed, in a manner similar to that of the other enzymes of the juice. In two of the experiments the activity of the secretion was greater than that of the gland, which was removed at the end of the experiment.

Parotid saliva was obtained from two pigs anæs. thetized with chloralose, and from two after decerebration under ethyl chloride and ether anæsthesia. Difficulty was experienced in estimating the cholinesterase activity in a satisfactory manner; but it was clear that acetylcholine was hydrolysed at a high rate by the parotid. saliva (saliva $30-640$ units/ ml. ; gland 4l0-670 units $/ \mathrm{gm}$. ; serum 10 units $/ \mathrm{ml}$.).

These preliminary experiments confirm that cholin. esterases may be secreted actively by glands. It is not yet possible to assess the significance of their presence in the secretions of digestive glands; but they may have some useful function in the lumen of the gut.

Department of Experimental Medicine,

$$
\text { R. A. MCCANCE }
$$

L. M. Brown Cambridge.

R. S. COMLINE

D. A. TITCHEN

Physiological Laboratory, Cambridge.

Aug. 5.

${ }^{1}$ Mendel, B., and Mundell, D. B., Biochem. J., 37, 64 (1943)

${ }^{3}$ Glick, D., Lewin, A., and Antopol, W., Proc. Soc. Exp. Biol., N.Y., 40, 28 '(1939).

${ }^{3}$ Ginsberg, R., Kohn, R., and Necheles, H., Amer. J. Digest. Dis., 4, 154 (1937).

"McCance, R. A., Hutchinson, A. O., Dean, R. F. A., and Jones,
P. J. H., Biochmm. J., 45, 493 (1949).

\section{Stimulation of Bile Secretion in Chick Embryos by Cortisone}

IN some preliminary experiments it was observed that the administration of cortisone to twelve-day old chick embryos caused their gall bladders to become distended and bile to flow prematurely into their intestines. Accordingly a substantial experiment was performed to confirm or deny these preliminary findings, and since there are certain difficulties associated with obtaining either rapid or complete absorption of substances injected into chick embryos, comparatively large doses of cortisone were employed. A dose of $5 \mathrm{mgm}$. of cortisone ("Cortone acetate') was given to each of sixty White Leghorn chick embryos on the twelfth day of incubation, either by injecting it into the yolk or on to the chorioallantoic membrane. For controls, seventy-five embryos were similarly injected with the same volume of normal saline. The eggs were harvested on the fifteenth day of incubation. The diameters and the lengths of the gall bladders were measured with calipers and their volumes were determined by assuming them to be cylinders. Observations were made in each instance on whether or not bile had reached the intestine to colour it green.

Forty of the sixty embryos receiving cortisone had larger gall bladders than the largest encountered in the control series. The average calculated volume of gall bladders in the cortisone group was $21 \cdot 1 \mathrm{c.mm}$. and that of those in the control series $6.9 \mathrm{c.mm}$. In twenty-eight of the cortisone-treated embryos, bile had reached the intestine to colour it green; this had not occurred in any of the control embryos.

The finding that cortisone can stimulate bile secretion raises the interesting question of how this effect is exerted. With regard to the possibility of the injected cortisone contributing to the formation of bile salts, which in turn produce the effect observed, it should be noted that in our experience the injection of sodium dehydrocholate into twelve-day old chick embryos also stimulates bile secretion; hence the liver at this stage of development is competent to respond to a bile salt stimulus. But since Paschkis, Cantarow, Walkling, Pearlman, Rakoff and Boyle ${ }^{1}$ have shown that carbohydrate-active oxysteroids can be recovered from the bile of dogs given adrenal cortical extracts, the possibility of cortisone being excreted as such into bile and, in being excreted, directly stimulating the flow of the medium in which it is contained, should also be considered.

We wish to acknowledge financial assistance from the National Cancer Institute of Canada and the Foster Bequest Fund of the University of Toronto.

M. M. Mosbaugh

Department of Anatomy,

A. W. HAM

University of Toronto. June 8.

${ }^{1}$ Paschkis, K. E., Cantarow, A., Walkling, A. A., Pearlman, W. H., Rakoff, A. E., and Boyle, D., Fed. Proc., 7,90 (1948).

\section{Antivitamin D Factor}

Rickets, attended by a reduction in gain of weight, has been frequently reported in weaned lambs grazing on green oat plants and other green feeds during the winter in the South Island of New Zealand ${ }^{1,2}$. The effect is not confined to green feeds grown in this country, since Ewer has demonstrated a rachitogenic effect of green oats grown in England ${ }^{3}$.

Previous work in New Zealand ${ }^{2,4,5}$ has shown that there is adequate calcium and phosphorus in the rickets-producing plants and that supplementary feeding of calcium and/or phosphorus does not prevent the disease. Rickets was prevented and normal growth-rate restored by a single massive dose of 'Calciferol' (1,000,000 i.u.) given at the commencement of green feed grazing 5 , but not by weekly doses of cod liver oil which provided an average of $300 \mathrm{i} . u$. of vitamin D a day, which is approximately twice the normal daily requirement of young sheep ${ }^{6}$. It was therefore postulated that a rachitogenic factor was present in the green feeds on which ovine rickets 